ISSN: $2354-1431$
http://tckh.daihoctantrao.edu.vn/

\title{
Đánh giá công tác quản lý nhà nước về khai thác khoáng sản trên địa bàn tỉnh Tuyên Quang giai đoạn 2011-2018 và đề xuất giải pháp đến năm 2030
}

\author{
Trịnh Phuoong Ngọc ${ }^{a^{*}}$, Kiều Thị Hải $i^{b}$, Trần Thị Nhung ${ }^{a}$ \\ ${ }^{a}$ Trường Đại học Tân Trào \\ ${ }^{b}$ Sở Tài nguyên và Môi trường Tuyên Quang \\ *Email: gemytrinh@gmail.com
}

\section{Thông tin bài viết}

Ngày nhận bài:

25/8/2019

Ngày duyệt đăng:

$10 / 12 / 2019$

\section{Tù khóa:}

Quản lý nhà nước; khai thác khoáng sản; đánh giá; giải pháp; Tuyên Quang

\begin{abstract}
Tóm tắt
Khai thác khoáng sản là một hoạt động đã và đang diễn ra trên địa bàn tỉnh Tuyên Quang. Với đặc thù của ngành công nghiệp khai khoáng là gây nhiều tác động tiêu cực tới môi trường nhưng lại đem về giá trị kinh tế cao, khiến cho việc quản lý nhà nước về khai thác khoáng sản thực sự gặp nhiều khó khăn khi phải tìm cách cân bằng giữa việc bảo vệ môi trường và phát triển kinh tế. Khoáng sản Tuyên Quang được phân bố ở hầu hết các huyện, thành phố trên địa bàn tỉnh và chủ yếu là các điểm mỏ phân tán nhỏ lẻ chỉ phù hợp với phát triển công nghiệp địa phương. Thực hiện tốt quản lý nhà nước về khai thác khoáng sản không chỉ giúp bảo vệ môi trường mà còn tăng nguồn thu ngân sách, phục vụ đắc lực cho phát triển kinh tế - xã hội của tỉnh. Nghiên cứu tập trung đánh giá công tác quản lý nhà nước về khai thác khoáng sản trên địa bàn tỉnh Tuyên Quang trong giai đoạn 2011-2018 và những giải pháp được đề xuất đến năm 2030.
\end{abstract}

\section{1. Đặt vấn đề}

Khai thác khoáng sản (KTKS) là hoạt động nhằm thu hồi khoáng sản, bao gồm xây dựng cơ bản mỏ, khai đào, phân loại, làm giàu và các hoạt động khác có liên quan [5]. KTKS được tiến hành sau khi đã có giấy phép khai thác của cơ quan nhà nước có thẩm quyền và được tính từ khi mỏ bắt đầu xây dựng cơ bản (hay còn gọi là mở mỏ) cho đến khi mỏ kết thúc khai thác (đóng cửa mỏ - phục hồi môi trường). Với chủ trương kinh tế hóa ngành tài nguyên và môi trường, khai thác khoáng sản thực sự được coi là một hoạt động kinh tế với thước đo là tiết kiệm, hiệu quả và mục tiêu là lợi ích.

Khoáng sản của tỉnh Tuyên Quang có nhiều về chủng loại, đa dạng cả về kim loại và phi kim loại. Trong đó, có những khoáng sản có giá trị kinh tế như: chì-kẽm, thiếc-vonfram, măng gan, barite, caolinfelspat... Theo tài liệu địa chất khoáng sản hiện có thì trên địa bàn tỉnh Tuyên Quang đã phát hiện và xác định được 200 mỏ, điểm mỏ khoáng sản và 86 điểm khoáng sản, điểm biểu hiện khoáng sản (chưa rõ triển vọng hoặc ít triển vọng) thuộc 31 loại khoáng sản khác nhau. Quặng barite phân bố chủ yếu ở các huyện Sơn Dương, Yên Sơn và Chiêm Hoá, có trữ lượng trên 2 triệu tấn. Măng gan tập trung chủ yếu ở các huyện Chiêm Hoá và một điểm ở huyện $\mathrm{Na}$ Hang, trong đó 2 điểm ở huyện Chiêm Hoá có trữ lượng khoảng 3,2 triệu tấn. Ăngtymoan phân bố ở các huyện Chiêm Hoá, $\mathrm{Na}$ Hang và Yên Sơn, trong đó 4 điểm tại Chiêm Hoá có trữ lượng 1,2 triệu tấn. Ở Tuyên Quang, ước tính có hàng tỷ $\mathrm{m}^{3}$ đá vôi, đáng chú ý nhất là hai mỏ đá vôi Tràng Đà trữ lượng khoảng trên 1 tỷ tấn, có hàm lượng cao từ $49-54 \%$ đủ tiêu chuẩn sản xuất xi măng mác cao; mỏ đá trắng Bạch Mã ở huyện Hàm Yên có trữ lượng khoảng 100 triệu $\mathrm{m}^{3}$, là nguyên liệu tốt để sản xuất đá ốp lát tiêu dùng trong nước và xuất khẩu. Có thể khẳng định rằng nguồn đá vôi của Tuyên Quang khá dồi dào, là loại khoáng sản có khả năng khai thác tốt nhất trong các loại khoáng sản để tạo ra 
một loại sản phẩm chủ lực. Đất sét được thấy ở nhiều nơi thuộc thành phố Tuyên Quang, trong đó đáng chú ý nhất mỏ sét bên cạnh mỏ đá vôi Tràng Đà được dùng để sản xuất xi măng. Ngoài các loại khoáng sản trên, Tuyên Quang còn có nhiều khoáng sản như vonfram, pirít, kẽm, cao lanh, sét chịu lửa, nước khoáng, vàng, cát, sỏi... đang được khai thác với quy mô nhỏ.

Hiện chưa có khái niệm cụ thể, chính xác thế nào là quản lý nhà nước về KTKS, song có thể hiểu quản lý nhà nước về KTKS là sự tác động có tổ chức, có mục đích của Nhà nước lên hoạt động KTKS để đảm bảo nguồn tài nguyên khoáng sản được khai thác hợp lý. Mục tiêu của quản lý nhà nước về KTKS là nhằm thực hiện mục tiêu phát triển kinh tế - xã hội của địa phương, hạn chế tác động xấu của hoạt động KTKS đến môi trường và bảo vệ quyền sở hữu toàn dân đối với khoáng sản mà Nhà nước là đại diện. Quản lý nhà nước về KTKS được thực hiện dựa trên 4 nguyên tắc: (1) tuân thủ pháp luật, chính sách về KTKS; (2) phải phù hợp với chiến lược, quy hoạch KTKS, (3) chỉ được tiến hành KTKS khi được cơ quan quản lý nhà nước có thẩm quyền cho phép và (4) phải đảm bảo hiệu quả kinh tế - xã hội và bảo vệ môi trường.

Theo Luật Khoáng sản năm 2010 và các Nghị định hướng dẫn thi hành, quản lý nhà nước về KTKS (xét trên phạm vi cấp tỉnh) gồm những nội dung chủ yếu sau: (1) Thực hiện pháp luật, chính sách, quy định của Nhà nước về khai thác khoáng sản; (2) Xây dựng quy hoạch, kế hoạch khai thác khoáng sản; (3) Tổ chức bộ máy quản lý nhà nước về khai thác khoáng sản; (4) Thực hiện các biện pháp bảo vệ môi trường, khoáng sản chưa khai thác, tài nguyên thiên nhiên khác theo quy định của pháp luật, bảo đảm an ninh, trật tự an toàn xã hội tại khu vực có khoáng sản; (5) Thanh tra, kiểm tra, giám sát, xử lý vi phạm pháp luật về KTKS.

Để đảm bảo thực hiện được những nội dung trên, các tiêu chí đánh giá quản lý nhà nước về khai thác khoáng sản gồm có:

- Thực hiện mục tiêu phát triển kinh tế - xã hội của địa phương. Mục tiêu quản lý nhà nước về KTKS là thực hiện mục tiêu phát triển kinh tế - xã hội. Quản lý nhà nước về KTKS có hiệu quả khi và chỉ khi nó đạt được mục tiêu đề ra, góp phần thực hiện mục tiêu phát triển kinh tế - xã hội nói chung. Tiêu chí thực hiện mục tiêu phát triển kinh tế xã hội có thể đánh giá thông qua các chỉ tiêu: GDP, tỷ trọng đóng góp ngành KTKS trong tổng GDP, giải quyết việc làm, thu nhập dân cư...
- Thu ngân sách nhà nước từ hoạt động KTKS. Chỉ tiêu thể hiện hiệu quả kinh tế - xã hội mà quản lý nhà nước về KTKS hướng tới, có thể khẳng định thu ngân sách là chỉ tiêu cơ bản, quan trọng nhất, dễ dàng kiểm chứng và đánh giá nhất. Khi đánh giá hiệu quả quản lý nhà nước về KTKS sản dựa trên tiêu chí thu ngân sách cần lưu ý rằng không phải chỉ đánh giá đơn thuần dựa trên quy mô ngân sách thu được (nhiều, ít) mà cần so sánh, đặt trong mối tương quan với quy mô hoạt động KTKS.

- Giảm mức độ ô nhiễm môi trường. Một đặc điểm của KTKS là hoạt động này có tác động lớn đến môi trường. Do đó, nhiệm vụ của Nhà nước trong quản lý là phải hạn chế sự tác động của hoạt động KTKS đến môi trường, bảo vệ sức khỏe của nhân dân, đặc biệt nhân dân vùng KTKS. Tiêu chí này có thể đánh giá thông qua thông qua kết quả của công tác thanh tra, kiểm tra về hoạt động bảo vệ môi trường trong KTKS, số lượng doanh nghiệp đã khắc phục vi phạm và thông qua công tác bảo vệ khoáng sản chưa khai thác.

Một số văn bản quy phạm pháp luật liên quan đến quản lý nhà nước về KTKS có thể kể đến như: Luật Khoáng sản năm 2010, Nghị định số 203/2013/NĐ-CP ngày 28/11/2013 quy định phương pháp tính, mức thu tiền cấp quyền KTKS, Nghị định số 158/2016/NĐ-CP ngày 29/11/2016 của Chính phủ hướng dẫn thi hành một số điều của Luật Khoáng sản và Nghị định số 33/2017/NĐ-CP ngày 03/4/2017 quy định về xử phạt vi phạm hành chính trong lĩnh vực tài nguyên nước và khoáng sản.

UBND các tỉnh, thành phố, nhất là các địa phương có nhiều khoáng sản đã thực hiện nhiều giải pháp nhằm phòng ngừa, ngăn chặn hoạt động KTKS trái phép bằng nhiều hình thức như: ban hành các công văn, chỉ thị nhằm bảo vệ khoáng sản chưa khai thác, các địa phương, các ngành chức năng công bố địa chỉ thư điện tử, số điện thoại đường dây nóng để tổ chức, cá nhân biết, phản ánh mọi thông tin về tình trạng KTKS trái phép trên địa bàn; tổ chức nhiều đợt truy quét, giải toả, tịch thu nhiều phương tiện phục vụ khai thác trái phép, xử phạt hành chính đối với các tổ chức cá nhân. Điển hình như các tỉnh: Lào Cai, Phú Thọ, Quảng Nam, Đồng Nai, Bà Rịa - Vũng Tàu, Bình Thuận, Lâm Đông, thành phố Hà Nội và thành phố Đà Nẵng, v.v...

Thu tiền cấp quyền KTKS là một biện pháp trong lộ trình minh bạch hóa hoạt động khai khoáng lần đầu thực hiện tại nước ta. Thái Nguyên là tỉnh đầu tiên 
hoàn thành thực thi chính sách này đã có được những kinh nghiệm quý báu. Để thực hiện thuận lợi, tỉnh đã thành lập Hội đồng thẩm định để xem xét, xác định số tiền các đơn vị phải nộp làm cơ sở trình UBND tỉnh phê duyệt. Sau khi có Quyết định phê duyệt số tiền cấp quyền KTKS sản của UBND tỉnh, Sở Tài nguyên và Môi trường (TNMT) đã phối hợp với Cục Thuế tỉnh để thông báo cho tổ chức, cá nhân được cấp quyền KTKS thực hiện theo quy định.

Ràng buộc được trách nhiệm của doanh nghiệp khai khoáng với nơi có khoáng sản sẽ giữ gìn được môi trường, đảm bảo sự phát triển bền vững ở địa phương. Theo kinh nghiệm của Lào Cai, tỉnh này đã thu phí vận chuyển từ doanh nghiệp khoáng sản để phục vụ chương trình cải tạo các tuyến đường xuống cấp nghiêm trọng. Do cả nước chưa quy định về thu cụ thể nên tỉnh tự xây dựng và ban hành mức thu dựa trên nguyên tắc: bảo đảm đủ tiền để xây dựng và sửa chữa đường trong khả năng đóng góp của doanh nghiệp và mức thu được điều chỉnh theo giá bán quặng. Được sự giải trình, phân tích thuyết phục của tỉnh, các doanh nghiệp đã thống nhất thực hiện việc đóng phí này. Ở Bình Định, UBND tỉnh đã ban hành quy định cụ thể mức đóng góp xây dựng cơ sở hạ tầng địa phương của doanh nghiệp KTKS và phân cấp quyền sử dụng kinh phí cho địa phương quản lý.

Về đấu giá quyền KTKS, Thanh Hóa là tỉnh đầu tiên trong cả nước thực hiện thành công quy định này. Trong năm 2014, nhiều địa phương đã phê duyệt kế hoạch đấu giá quyền KTKS. Bước đầu đã có một số tỉnh tổ chức đấu giá thành công như: Quảng Bình đấu giá quyền KTKS 03 mỏ cát làm VLXDTT với tổng số tiền là 1.382.290.000 đồng; Kon Tum đấu giá quyền KTKS 09 điểm mỏ cát, sỏi trên lòng sông Đăk Bla, thành phố Kon Tum với tổng số tiền là 2.183.900.000 đồng; Quảng Ngãi đấu giá quyền KTKS một số điểm mỏ với tổng số tiền là 5,142 tỷ đồng.

Để quản lý hiệu quả hoạt động khoáng sản, ngày 19/3/2018, UBND tỉnh Tuyên Quang đã ban hành Quyết định số 02/2018/QĐ-UBND Quy định về trách nhiệm của các cấp, các ngành trong quản lý đất đai, khoáng sản trên địa bàn tỉnh. Theo đó, trên cơ sở chức năng, nhiệm vụ, quyền hạn được giao, tùy theo tính chất, nội dung của công tác quản lý hoạt động khoáng sản, các cơ quan trên địa bàn tỉnh Tuyên Quang thực hiện theo đúng nguyên tắc, nghiệp vụ, chuyên môn, chế độ bảo mật của mỗi cơ quan, bảo đảm kết quả phối hợp đạt chất lượng và thời gian yêu cầu; đảm bảo tính thống nhất, tập trung; không hình thức, chồng chéo, bỏ sót nhiệm vụ làm ảnh hưởng đến hiệu quả chung về công tác quản lý hoạt động khoáng sản; đảm bảo sự phối hợp đồng bộ; đề cao trách nhiệm của cơ quan chủ trì, cơ quan phối hợp.

Nhìn rộng hơn đối với các quốc gia trong khu vực, một số tỉnh ở Indonesia đã xây dựng những quy định cụ thể về hỗ trợ địa phương đối với các doanh nghiệp KTKS; áp dụng quy trình tham vấn trong cấp phép nhằm hạn chế xung đột và thực hiện công khai nguồn thu từ khai thác tài nguyên khoáng sản. Ở Philippine, về chức năng quản lý ở cấp địa phương phân làm hai loại: Một là, Ban quản lý KTKS ở tỉnh chịu trách nhiệm về quản lý các mỏ khai thác quy mô nhỏ; Hai là, nhóm giám sát của các bên liên quan, giám sát hoạt động khai khác đối với các thành viên quy mô lớn, khi thực thi đã đem đến những kết quả tích cực như: tăng doanh thu, tăng ngân sách, tăng cường sự tham gia của các bên, phát triển nhận thức xã hội và môi trường.

\section{Phương pháp nghiên cứu}

Phương pháp thu thập dữ liệu thứ cấp được sử dụng kết hợp với phân tích, đánh giá tổng hợp, thống kê, so sánh để đưa ra bức tranh tổng quan nhất về hiện trạng quản lý nhà nước về KTKS trên địa bàn tỉnh Tuyên Quang giai đoạn 2011-2018, từ đó đề xuất các giải pháp đến năm 2030. Trong đó, các dữ liệu được sử dụng chủ yếu từ các quy định, báo cáo của cơ quan quản lý nhà nước về KTKS các cấp, gồm các văn bản luật, nghị định, thông tư quy định, hướng dẫn về KTKS, quản lý nhà nước về KTKS và quy hoạch, các quy định, báo cáo của UBND tỉnh Tuyên Quang, các Sở, ngành thuộc tỉnh trong giai đoạn 2011-2018 và niên giám thống kê của Tổng cục Thống kê và Cục Thống kê tỉnh Tuyên Quang. Trên cơ sở các tài liệu, số liệu thu thập được, tiến hành phân loại, đánh giá, tính toán và lựa chọn các nội dung, số liệu phù hợp với mục đích nghiên cứu.

\section{Kết quả nghiên cứu}

3.1. Thục trạng quản lý nhà nước về khai thác khoáng sản tại tỉnh Tuyên Quang

3.1.1. Thực hiện pháp luật, chính sách, quy định của Nhà nước về khai thác khoáng sản

Việc cấp phép đảm bảo theo các điều kiện quy định. Tính đến ngày 31/12/2018, trên địa bàn tỉnh Tuyên Quang đã cấp 105 Giấy phép KTKS còn hiệu lực, trong đó Bộ TNMT cấp 14 giấy phép, 91 giấy phép do UBND tỉnh cấp $[10,11]$.

Công tác tính, phê duyệt tiền cấp quyền KTKS: Đến ngày 31/12/2018, UBND tỉnh Tuyên Quang đã 
ban hành 112 Quyết định phê duyệt tiền cấp quyền KTKS với tổng số tiền 209,8 tỷ đồng. Nếu tính cả 13 quyết định phê duyệt tiền cấp quyền KTKS của Bộ TNMT với tổng số tiền 114,6 tỷ đồng thì tổng số đã có 125 Quyết định phê duyệt tiền cấp quyền KTKS đối với các mỏ khai thác trên địa bàn tỉnh với tổng số tiền 324,4 tỷ đồng [3].

Công tác thu tiền cấp quyền KTKS từ năm 2014 đến năm 2018: Theo các quyết định đã phê duyệt, tổng số tiền cấp quyền KTKS phải thu là 189,9 tỷ đồng, đã thu được được 155,4 tỷ, số còn phải thu là 34,5 tỷ đồng [3].

Trong giai đoạn 2011-2018, UBND tỉnh Tuyên Quang đã phê duyệt Quy hoạch phát triển VLXD tỉnh Tuyên Quang đến năm 2020 (Quyết định 12/2011/QĐ-UBND ngày 08/6/2011); Sửa đổi, bổ sung Quy hoạch điều tra, đánh giá, thăm dò, khai thác và sử dụng khoáng sản tỉnh Tuyên Quang đến năm 2010, có xét đến năm 2020 ban hành kèm theo Nghị quyết số 97/2006/NQ-HĐND ngày 08 tháng 12 năm 2006 của Hội đồng nhân dân tỉnh (Nghị Quyết 14/2017/NQ-HĐND ngày 26/7/2017); Phê duyệt báo cáo điều chỉnh, bổ sung quy hoạch thăm dò, khai thác, sử dụng khoáng sản đến năm 2030 (Quyết định 514/QĐ-UBND ngày 31/12/2017); Ban hành quy định về trách nhiệm của các cấp, các ngành trong quản lý đất đai, khoáng sản trên địa bàn tỉnh Tuyên Quang (số 02/2018/QĐ-UBND ngày 19/3/2018) và ra quyết định về việc ban hành phương án bảo vệ khoáng sản chưa khai thác trên địa bàn tỉnh Tuyên Quang (số 77/QĐUBND ngày 23/3/2018).

Từ năm 2011 đến nay, UBND tỉnh Tuyên Quang đã ban hành một số văn bản quy phạm pháp luật và văn bản chỉ đạo, điều hành về KTKS: 04 Văn bản quy phạm pháp luật; 23 văn bản chỉ đạo. Các văn bản, chính sách, quy định của UBND tỉnh Tuyên Quang về KTKS giai đoạn 2011-2018, ngoài việc đã bám sát và cụ thể hóa việc thực hiện Luật Khoáng sản 2010 và các văn bản hướng dẫn thực hiện, tạo điều kiện cho tổ chức, cá nhân quản lý, hoạt động khoáng sản dễ áp dụng, góp phần có hiệu quả vào công tác quản lý nhà nước đối với hoạt động khoáng sản và tháo gỡ kịp thời khó khăn, vướng mắc cho doanh nghiệp, nâng cao chất lượng cải cách hành chính ngành tài nguyên môi trường, còn có những quy định riêng đặc thù để thực hiện quy hoạch, kế hoạch KTKS của địa phương
3.1.2. Tổ chức bộ máy quản lý nhà nước về khai thác khoáng sản

Hiện nay, nhiệm vụ chủ trì giúp UBND tỉnh quản lý nhà nước về khoáng sản nói chung, KTKS nói riêng trên địa bàn tỉnh được giao cho Sở TNMT.

Tại cấp huyện, nhiệm vụ quản lý nhà nước về khoáng sản được giao cho Phòng TNMT chủ trì thực hiện. Các xã có khoáng sản và hoạt động khoáng sản phân công một công chức xã kiêm nhiệm giúp xã thực hiện chức năng quản lý khoáng sản trên địa bàn xã.

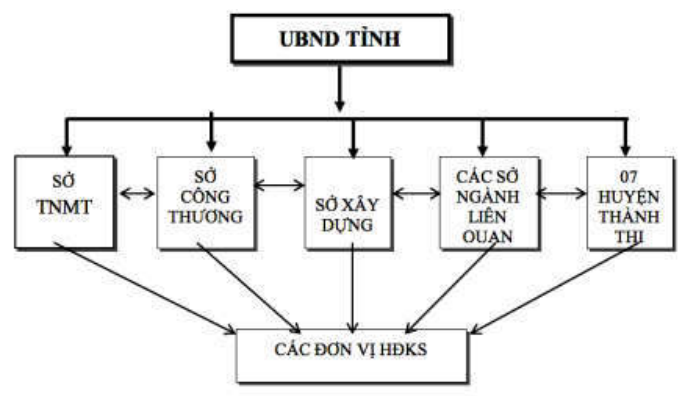

Hình 1. So đồ bộ máy công tác quản lý nhà nước về tài nguyên khoáng sản tỉnh Tuyên Quang

Ngoài trách nhiệm quản lý nhà nước về KTKS của Sở TNMT, UBND cấp huyện, xã, theo quy định tại Quyết định số 02/2018/QĐ-UBND ngày 19/3/2018 của UBND tỉnh, một số Sở, ngành cũng được phân công nhiệm vụ cụ thể trong quản lý nhà nước về KTKS. Bên cạnh việc phân định rõ nhiệm vụ cụ thể theo từng cơ quan, đơn vị, tỉnh đã giao Giám đốc các Sở, ngành, Chủ tịch UBND cấp huyện, xã phải chịu trách nhiệm về công tác quản lý hoạt động khoáng sản thuộc chức năng, nhiệm vụ của đơn vị; đối với những nhiệm vụ liên quan đến nhiều cơ quan, đơn vị, UBND tỉnh giao rõ đơn vị chủ trì, đơn vị phối hợp, quy định cơ chế phối hợp. Do vậy trách nhiệm của các cơ quan, đơn vị trong quản lý nhà nước về KTKS được tăng cường, sự phối hợp giữa các Sở, ngành và giữa Sở, ngành với UBND cấp huyện được thực hiện đảm bảo ngày càng chặt chẽ, đồng bộ, kịp thời, hạn chế tình trạng né tránh, đùn đẩy trách nhiệm, góp phần tăng cường hiệu lực, hiệu quả quản lý nhà nước.

3.1.3. Việc khoanh định phê duyệt các khu vưc cấm, tạm cấm hoạt động khoáng sản và xây dựng phê duyệt quy hoạch khoáng sản

Thực hiện nguyên tắc KTKS phải gắn với bảo vệ cảnh quan thiên nhiên, bên cạnh các tiêu chí Luật định, tỉnh đã bổ sung quy định về đảm bảo cảnh quan môi trường là một căn cứ để khoanh định khu vực cấm hoạt động khoáng sản. Quy định trên đã được hiện thực hóa trong Quyết định phê duyệt khoanh định khu 
vực cấm hoạt động khoáng sản trên địa bàn tỉnh với 18 khu vực được khoanh định cấm hoạt động khoáng sản và 12 khu vực hạn chế hoạt động khoáng sản là để đảm bảo cảnh quan môi trường.

Công tác lập quy hoạch tài nguyên khoáng sản trên địa bàn Tỉnh theo thẩm quyền đến nay đã khá đầy đủ. Với mục tiêu tổng hợp và đánh giá một cách toàn diện và có hệ thống tiềm năng tài nguyên khoáng sản, hiện trạng công nghiệp khoáng sản, tình hình sử dụng khoáng sản và giá trị kinh tế khoáng sản trên địa bàn tỉnh Tuyên Quang. Ngoài ra, để hệ thống hóa thông tin quản lý về khoáng sản, UBND tỉnh đã chỉ đạo Sở TNMT thực hiện Dự án xây dựng hệ thống cơ sở dữ liệu phục vụ công tác quản lý tài nguyên khoáng sản tỉnh Tuyên Quang, đã được Uỷ ban nhân dân tỉnh phê duyệt tại Quyết định số 680/QĐ-UBND ngày 24/10/2007.

\subsubsection{Công tác thanh tra, kiểm tra}

Thông qua thanh tra, kiểm tra, nhiều sai phạm đã được phát hiện và xử lý, hạn chế những sai sót trong hoạt động khoáng sản, góp phần nâng cao ý thức tuân thủ pháp luật của các tổ chức, cá nhân, truy thu các khoản thuế, phí..., thực hiện các biện pháp giảm thiểu ô nhiễm môi trường, khắc phục tình trạng mất an toàn lao động, khai thác vượt mốc giới, góp phần tăng cường hiệu lực, hiệu quả quản lý, đưa hoạt động KTKS trên địa bàn tỉnh dần đi vào nề nếp.

Từ năm 2011 đến năm 2017, cơ quan quản lý nhà nước về KTKS trên địa bàn tỉnh Tuyên Quang đã kiểm tra và yêu cầu 57 doanh nghiệp khắc phục các vi phạm trong hoạt động khoáng sản trong thời gian 90 ngày; thu hồi 06 giấy phép khai thác, trả lại 02 giấy phép khai thác; đóng cửa mỏ 70 giấy phép; dừng thực hiện 20 dự án; xử phạt vi phạm hành chính 2,7 tỷ đồng. Trong 3 năm từ 2016 đến 2018, các cơ quan chức năng của tỉnh Tuyên Quang, Ủy ban nhân dân huyện, thành phố đã thanh tra, kiểm tra xử lý 12 doanh nghiệp trong khai thác khoáng sản với số tiền xử phạt vi phạm hành chính 390 triệu đồng. Tổ chức 575 đợt kiểm tra, phát hiện và xử lý 229 vụ với tổng số tiền xử phạt vi phạm hành chính 3,63 tỷ đồng; tịch thu 8.047 tấn quặng chì-kẽm, 1,029 tấn quặng thiếc, 287 tấn quặng barite, $1.800 \mathrm{~m}^{3}$ cát bán xung công quỹ nhà nước [10, 11]. Năm 2017 và 2018, Sở TNMT đã phối hợp Đoàn kiểm tra của Tổng cục Địa chất và Khoáng sản Việt Nam, kiểm tra 17 doanh nghiệp hoạt động khai thác khoáng sản trên địa bàn tỉnh; phối hợp Đoàn Thanh tra Chính phủ tiến hành thanh tra 17 doanh nghiệp về việc thực hiện pháp luật về bảo vệ môi trường trong hoạt động khai thác khoáng sản trên địa bàn tỉnh Tuyên Quang. Qua đó, đã yêu cầu các doanh nghiệp khắc phục ngay thiếu sót, tồn tại, thực hiện các biện pháp bảo vệ môi trường trong hoạt động KTKS.

\subsubsection{Công tác bảo vệ khoáng sản chura khai thác}

Công tác bảo vệ khoáng sản chưa khai thác được thực hiện theo quy định của pháp luật và các Quyết định của UBND tỉnh: Quyết định số 1446/QĐ-CT ngày 20/11/2012 về việc thành lập Ban chỉ đạo tăng cường công tác quản lý hoạt động khoáng sản trên địa bàn tỉnh; Quyết định số 1077/QĐ-UBND ngày 01/9/2015 về việc kiện toàn ban chỉ đạo tăng cường công tác quản lý hoạt động khoáng sản trên địa bàn tỉnh; Quyết định số 1078/QĐ-UBND ngày 01/9/2015 về việc thành lập tổ công tác liên ngành kiểm tra hoạt động khoáng sản khai thác cát, sỏi lòng sông trên địa bàn tỉnh Tuyên Quang; Quyết định số 1181/QĐUBND ngày 14/10/2017 của Ủy ban nhân dân tỉnh về việc thành lập Ban chỉ đạo tăng cường công tác quản lý hoạt động khoáng sản trên địa bàn tỉnh; Quyết định số 1242/QĐ-UBND ngày 28/10/2017 của Ủy ban nhân dân tỉnh về việc kiện toàn Tổ công tác liên ngành kiểm tra hoạt động khoáng sản khai thác cát, sỏi lòng sông trên địa bàn tỉnh Tuyên Quang... Theo đó, các cơ quan quản lý nhà nước về KTKS trên địa bàn tỉnh Tuyên Quang đã thường xuyên tổ chức các đợt truy quét, chấn chỉnh kịp thời các tụ điểm khai thác khoáng sản trái phép, xử lý nghiêm các trường hợp vi phạm theo quy định của pháp luật [13].

\section{2. Đánh giá công tác quản lý nhà nước về khai} thác khoáng sản tại tỉnh Tuyên Quang

Hoạt động quản lý nhà nước về tài nguyên khoáng sản trên địa bàn tỉnh Tuyên Quang ngày càng đi vào nề nếp, ổn định, hoạt động khoáng sản ngày càng có hiệu quả, góp phần thúc đẩy sự phát triển kinh tế - xã hội chung của Tỉnh. Các mặt đạt được cụ thể như sau:

Công tác tham mưu xây dựng, ban hành các văn bản hướng dẫn thi hành pháp luật Khoáng sản được chú trọng thực hiện, đã kịp thời tạo ra một hệ thống văn bản pháp luật tương đối hoàn chỉnh góp phần ổn định và là công cụ đắc lực trong công tác quản lý, bảo vệ tài nguyên khoáng sản của tỉnh. Đã hoàn thành Quy hoạch khoáng sản, khoanh định và phê duyệt khu vực không đấu giá quyền KTKS, tạo nền tảng, là cơ sở cho công tác quản lý và lập lại trật tự trong hoạt động KTKS; là cơ sở định hướng để chuyển khai thác ngắn hạn, thủ công, hiệu quả thấp, nguy cơ cao mất an toàn lao động sang khai thác chế biến quy mô công nghiệp, 
công nghệ tiên tiến, hiệu quả cao hơn và đảm bảo an toàn lao động hơn.

Việc cấp phép hoạt động khoáng sản được chấn chỉnh ngày càng chặt chẽ theo quy định của pháp luật về khoáng sản. Bước đầu đã quản lý được khối lượng KTKS, đặc biệt là khoáng sản đá làm vật liệu xây dựng thông thường, đá vôi, sét xi măng. Việc tính tiền cấp quyền $\mathrm{KTKS}$ và thu tiền cấp quyền $\mathrm{KTKS}$ các năm từ năm 2014 đến nay được triển khai thực hiện nghiêm túc và đạt kết quả tích cực; cấp, gia hạn, đóng cửa mỏ khoáng sản được thực hiện theo cơ chế "một cửa”, quy chế phối hợp trong công tác tiếp nhận, giải quyết hồ sơ đề nghị hoạt động khoáng sản được thực hiện quy định, phù hợp quy hoạch đáp ứng được nhu cầu khai thác, sử dụng khoáng sản của tỉnh.

Công tác kiểm tra, thanh tra các hoạt động thăm dò, khai thác, chế biến khoáng sản được tăng cường, xử lý vi phạm về KTKS được đẩy mạnh, có hiệu quả hơn giai đoạn trước, góp phần hạn chế các trường hợp vi phạm trong KTKS, nâng cao ý thức tuân thủ pháp luật về khoáng sản của các tổ chức, cá nhân, người dân và các cơ quan, tổ chức; tình trạng $\mathrm{KTKS}$ trái phép đã giảm, ý thức tuân thủ pháp luật về khoáng sản của các tổ chức, cá nhân cũng như của người dân và các cơ quan, tổ chức đã được nâng cao.

Các khoá tập huấn về Luật khoáng sản, Luật sửa đổi, bổ sung một số điều của Luật khoáng sản và các văn bản liên quan được tổ chức cho lãnh đạo các ngành, cán bộ, chuyên viên, lãnh đạo các huyện, giám đốc doanh nghiệp, giám đốc điều hành mỏ và cán bộ quản lý hoạt động khoáng sản trên địa bàn tỉnh. Hướng dẫn các doanh nghiệp hoạt động theo Luật khoáng sản và các văn bản pháp dưới luật như các thông tư, nghị định, các quy định có liên quan khác để doanh nghiệp hoạt động khoáng sản đúng pháp luật.

Tổ chức bộ máy quản lý nhà nước về KTKS trên địa bàn tỉnh đã phân định rõ nhiệm vụ của từng cơ quan quản lý, cơ chế phối hợp, khắc phục tình trạng né tránh, đùn đẩy trách nhiệm, góp phần nâng cao hiệu quả quản lý. Nhờ thực hiện tốt các nội dung nêu trên, quản lý nhà nước về KTKS trên địa bàn tỉnh Tuyên Quang thời gian qua đã đạt được những kết quả tích cực, thể hiện qua các tiêu chí sau:

Chỉ số sản xuất công nghiệp năm 2017 tăng 9,03\% so với năm 2016, trong đó ngành khai khoáng giảm 18,9\% [4]. Trong năm 2017, ngành công nghiệp của tỉnh đã từng bước vượt qua những thách thức, khẳng định là một trong những khâu quan trọng trong sản xuất. Hoàn thành đưa vào vận hành dây chuyền sản xuất cán thép của Công ty trách nhiệm hữu hạn (TNHH) Gang thép Tuyên Quang. Trên biểu đồ hình 2 thể hiện chỉ số sản xuất công nghiệp ngành khai khoáng tăng, giảm không đáng kể trong 3 năm gần đây. Qua số liệu trên cho thấy, những năm gần đây nền kinh tế của tỉnh không còn phụ thuộc vào khai thác tài nguyên khoáng sản.

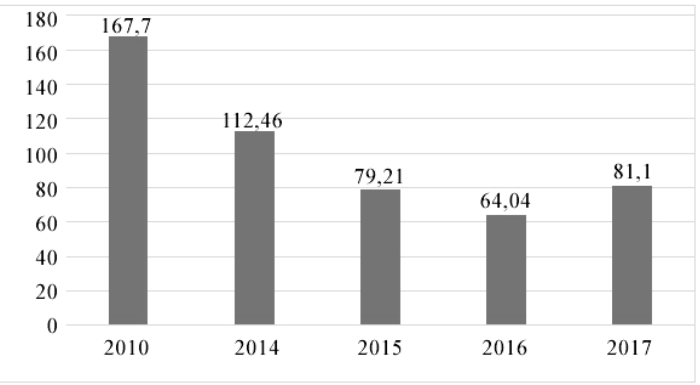

Hình 2. Biểu đồ chỉ số sản xuất công nghiệp ngành khai khoáng qua các năm [4].

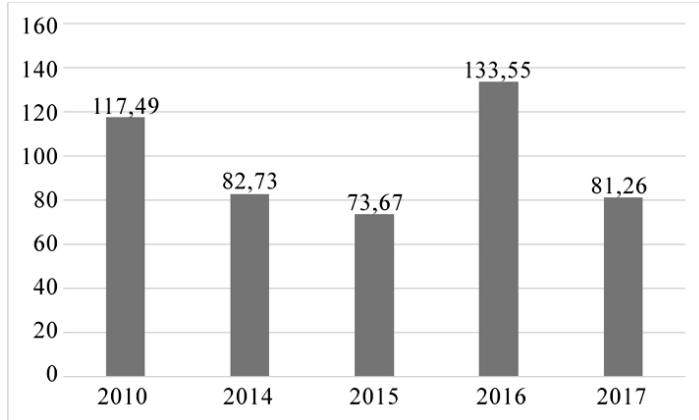

Hình 3. Biểu đồ chỉ số sản xất khai thác quặng kim loại theo các năm [4]

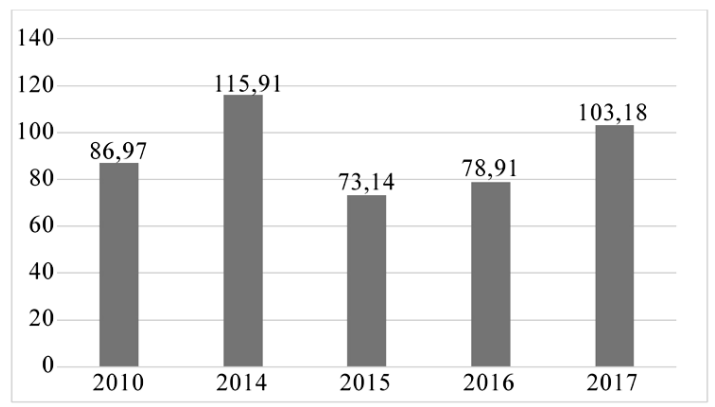

Hinh 4. Biểu đồ chỉ số sản xất khai thác đá và mỏ khác theo các năm [4]

Chỉ số sản xuất khai thác quặng kim loại: Biểu đồ hình 3 thể hiện chỉ số sản xuất khai thác quặng kim loại năm 2016 tăng vọt, còn năm 2017 giảm 39,2\% so với năm 2016.

Chỉ số sản xuất khai thác đá và mỏ khác: biểu đồ hình 4 thể hiện chỉ số sản xuất khai thác đá và các mỏ khác năm 2017 tăng 30,8\% so với năm 2016. 
Bên cạnh những mặt tích cực đã đạt được, công tác quản lý khoáng sản trên địa bàn tỉnh Tuyên Quang còn một số tồn tại tập trung vào các mặt sau đây:

- Chính quyền địa phương các cấp chưa thực hiện hết chức trách nhiệm vụ được giao; việc kiểm tra, phát hiện vi phạm đã có xử lý nhưng vẫn còn một số tổ chức và cá nhân có hành vi vi phạm pháp luật về khoáng sản. Chưa có sự phối hợp kịp thời trong công tác quản lý hoạt động KTKS và các vấn đề liên quan đến an ninh trật tự ở địa bàn giáp ranh giữa các tỉnh còn nhiều bất cập. Các đối tượng lợi dụng đêm tối để hoạt động trái phép nên gây không ít khó khăn cho công tác quản lý. Cán bộ quản lý nhà nước của Tỉnh ở các cấp ngành, có chuyên môn về Mỏ- Địa chất còn thiếu, một số sở ngành liên quan đến công tác này còn chưa có cán bộ có chuyên môn để tham mưu.

- Tình trạng KTKS trái phép còn diễn ra phát sinh nhiều ý kiến phản ánh, khiếu nại của cử tri; tình trạng khai báo thuế không đầy đủ làm thất thu ngân sách nhà nước.

- Việc thanh tra, kiểm tra về hoạt động khoáng sản chưa kịp thời, chưa thường xuyên. Chưa kiên quyết xử lý các sai phạm trong hoạt động khoáng sản.

\section{3. Đề xuất các giải pháp quản lý nhà nước về khai thác khoáng sản tại tỉnh Tuyên Quang}

Cần sớm hoàn thiện pháp luật, chính sách, quy định của Nhà nước về KTKS và việc thực hiện trên địa bàn tỉnh Tuyên Quang. Luật Khoáng sản năm 2010 quy định việc cấp phép KTKS phải có "quyết định phê duyệt trữ lượng khoáng sản của cơ quan nhà nước có thẩm quyền". Tuy nhiên, thực tế đối với hoạt động khai thác cát lòng sông, do thường xuyên được bồi lắng và thay đổi nên rất khó khăn cho công tác thăm dò, đánh giá. Do vậy, cần có những hướng dẫn chi tiết trong việc thực hiện phát luật về quản lý nhà nước trong hoạt động khai thác khoáng sản trên địa bàn tỉnh, đặc biệt đối với hoạt động khai thác cát lòng sông. Bên cạnh đó, cần xây dựng và triển khai Đề án hoàn thiện hệ thống cơ quan quản lý nhà nước về khoáng sản, xây dựng cơ chế phối hợp giữa Bộ, ngành, UBND các tỉnh, thành phố trực thuộc TW.

Tiếp tục thực hiện các chính sách, quy định riêng đặc thù của tỉnh, qua thực tiễn khẳng định được sự phù hợp, hiệu quả. Đồng thời rà soát để điều chỉnh, bổ sung, ban hành kịp thời các quy định, chính sách về KTKS trên nguyên tắc tuân thủ Hiến pháp và pháp luật, minh bạch, rõ trách nhiệm của các chủ thuể liên quan là "Nhà nước - người dân - doanh nghiệp", điều tiết hài hòa lợi ích mang lại từ hoạt động khoáng sản, đồng thời phù hợp với tính hình thực tế của địa phương, đảm bảo thực hiện hiệu quả quy hoạch, kế hoạch KTKS của tỉnh.

Hoàn thiện công tác thanh tra, kiểm tra hoạt động khai thác khoáng sản. Kiểm tra, giám sát Ủy ban nhân dân cấp huyện, xã trong công tác quản lý nhà nước về khoáng sản. Tăng cường sự phối hợp giữa các cấp, các ngành trong thanh tra, kiểm tra và giám sát, đôn đốc việc thực hiện kết luận thanh tra, thông báo khắc phục vi phạm. Ngoài ra, cần phối hợp chặt chẽ với Bộ TNMT trong việc thanh tra, kiểm tra đối với các trường hợp thuộc thẩm quyền cấp phép của Bộ và đôn đốc, giám sát doanh nghiệp thực hiện kết luận thanh tra.

Xem xét cấp Giấy phép khai thác cho những doanh nghiệp thực sự có năng lực đầu tư, ưu tiên các doanh nghiệp đã đầu tư KTKS nhiều năm hiện tại mỏ cũ đã hết trữ lượng hoặc mở rộng mỏ. Thực hiện công tác đấu giá quyền $\mathrm{KTKS}$ theo hướng vừa làm vừa rút kinh nghiệm. Kịp thời phản ánh những khó khăn, vướng mắc trong quá trình thực hiện về Bộ TNMT để báo cáo Thủ tướng Chính phủ chỉ đạo, xử lý. Đảm bảo sự phối hợp chặt chẽ giữa Sở TNMT và Cục Thuế tỉnh trong việc tính và thu tiền cấp quyền $\mathrm{KTKS}$. Sau khi có Quyết định phê duyệt tiền cấp quyền $\mathrm{KTKS}$, nhanh chóng gửi thông báo để doanh nghiệp biết và chủ động thực hiện.

Ứng dụng khoa học kĩ thuật vào quản lý nhà nước về $\mathrm{KTKS}$. Cập nhật thường xuyên và kịp thời kết quả đo mỏ vào phần mềm quản lý và công khai kết quả đo mỏ trên Cổng Thông tin điện tử của Sở TNMT tỉnh Tuyên Quang. Xử lý nghiêm các doanh nghiệp không đo mỏ; nếu chậm 01 năm thì tính theo công suất khai thác ghi trong giấy phép, chậm 2 năm thì kiểm tra, xử lý, tước quyền sử dụng giấy phép. Phối hợp chặt chẽ các công cụ pháp luật, kĩ thuật và kinh tế để đảm bảo đạt hiệu quả cao trong quản lý nhà nước về KTKS.

\section{Kết luận}

Xã hội càng phát triển thì nhu cầu của con người càng cao, do đó sức ép đối với tài nguyên khoáng sản ngày càng lớn. Để KTKS một cách hợp lý, tiết kiệm và hiệu quả thì quản lý nhà nước về KTKS là nhân tố mang ý nghĩa quyết định, điều đó đòi hỏi hoạt động này ngày càng phải được hoàn thiện. Thời gian qua, quản lý nhà nước về KTKS trên phạm vi cả nước đã có những chuyển biến tích cực, ngày càng hoàn thiện hơn. Cùng với đó, quản lý nhà nước về KTKS trên địa bàn tỉnh Tuyên Quang cũng ngày càng chặt chẽ, hiệu quả, tuy nhiên vẫn còn những tồn tại, hạn chế cần khắc phục. 
Bám sát khung lý thuyết và phân tích thực trạng, việc hoàn thiện công tác quản lý nhà nước về KTKS trên địa bàn tỉnh Tuyên Quang được trình bày trên 5 nhóm giải pháp: Hoàn thiện pháp luật, chính sách, quy định của Nhà nước về KTKS và việc thực hiện trên địa bàn tỉnh; hoàn thiện quy hoạch, kế hoạch KTKS; hoàn thiện cơ cấu bộ máy quản lý KTKS; hoàn thiện chính sách, quy định thực hiện quy hoạch, kế hoạch KTKS và hoàn thiện công tác thanh tra, kiểm tra hoạt động KTKS. Tuy nhiên, để hoàn thiện quản lý nhà nước về KTKS trên địa bàn một địa phương như tỉnh Tuyên Quang, thì ngoài các giải pháp mang tính tự thân trong nội bộ tỉnh cũng cần có cơ chế, chính sách quản lý đồng bộ, hoàn chỉnh từ phía các cơ quan Nhà nước ở trung ương.

\section{Kiến nghị với Bộ TNMT:}

Theo quy định tại điểm $\mathrm{c}$, khoản 2, Điều 55 Luật Khoáng sản quy định quyền và nghĩa vụ của tổ chức cá nhân KTKS "Đăng ký ngày bắt đầu xây dưng co' bản mỏ, ngày bắt đầu khai thác với co quan quản lý nhà nước có thẩm quyền cấp giấy phép và thông báo cho Ủy ban nhân dân các cấp nơi có mỏ truớc khi thực hiện". Tại khoản 1, Điều 66 Luật Khoáng sản quy định về việc chuyển nhượng quyền khai thác "Tổ chưc, cá nhân được cấp Giấy phép KTKS đã hoàn thành công tác xây dụng co bản, đưa mỏ vào khai thác thì được chuyển nhuợng quyền KTKS'. Do đó, việc đăng ký xây dựng cơ bản mỏ của các doanh nghiệp KTKS là việc rất quan trọng, tuy nhiên chưa có quy định về mẫu văn bản đăng ký xây dựng cơ bản mỏ, mẫu đăng ký ngày bắt đầu khai thác và việc kiểm tra xác nhận về nội dung đăng ký xây dựng cơ bản mỏ, xác nhận việc hoàn thành xây dựng cơ bản mỏ. Tương tự, tại Điều 20 Luật Khoáng sản quy định "Nhà nuoóc bảo đảm kinh phí cho công tác bảo vẹ khoáng sản chua khai thác. Kinh phí cho công tác bảo vệ khoáng sản chua khai thác được bố trí trong $d u$ toán ngân sách nhà nuoớc hằng năm", tuy nhiên hiện nay chưa có văn bản nào quy định cụ thể việc xây dựng phương án, định mức chi, quản lý kinh phí cho công tác bảo vệ khoáng sản chưa khai thác.

Từ thực tiễn triển khai cho thấy một số quy định trong Luật Khoáng sản còn chưa đầy đủ, thiếu cụ thể cần có hướng dẫn chi tiết, một số nội dung, quy định trong Nghị định số 22/2012/NĐ-CP ngày 26/3/2012 quy định về đấu giá quyền $\mathrm{KTKS}$ cần thiết được sửa đổi, bổ sung. Bộ TNMT cần khẩn trương nghiên cứu để sớm tham mưu Chính phủ đề nghị Quốc hội sửa đổi Luật Khoáng sản và trình Chính phủ Nghị định sửa đổi, bổ sung Nghị định số 22/2012/NĐ-CP ngày 26/3/2012 quy định về đấu giá quyền KTKS đảm bảo tính khả thi, thuận lợi cho triển khai thực hiện, góp phần nâng cao hiệu lực, hiệu quả quản lý nhà nước về KTKS.

\section{TÀI LIÊU THAM KHẢO}

1. Bộ Chính trị, 2011. Nghị quyết số $02 / \mathrm{NQ} / \mathrm{TW}$ ngày 25 tháng 4 năm 2011 về định hướng chiến lược khoáng sản và công nghiệp khai khoáng đến năm 2020, tầm nhìn đến năm 2030.

2. Chính phủ, 2016. Nghị định 158/2016/NĐ-CP ngày 29/11/2016 quy định chi tiết thi hành một số điều của Luật khoáng sản.

3. Cục Thuế tỉnh Tuyên Quang: Báo cáo kết quả thu, nộp các khoản thuế, phí phần chênh lệch giữa đo mỏ và kê khai thuế của doanh nghiệp, tiền cấp quyền KTKS các năm từ 2010 đến năm 2017.

4. Cục Thống kê tỉnh Tuyên Quang: Niên giám thống kê năm 2017. Nhà xuất bản thống kê.

5. Quốc hội, 2010. Luật Khoáng sản số 60/2010/QH12 ngày $17 / 10 / 2010$.

6. Lại Hồng Thanh, Tổng cục Địa chất và Khoáng sản Việt Nam, Bộ TNMT, 2017. Tăng cường quản lý nhà nước về khoáng sản, Tạp chí Tài nguyên và Môi trường, kỳ 2 tháng 2/2017, trang 10-11.

7. Thủ tướng Chính phủ, 2011. Quyết định số 2427/QĐ-TTg ngày 22/12/2011 phê duyệt chiến lược khoáng sản đến năm 2020, tầm nhìn đến năm 2030.

8. Trần Thanh Thủy và cộng sự, 2012. Khoáng sản Phát triển - Môi trường: Đối chiếu giữa lý thuyết và thực tiễn, Hà Nội, Nhà xuất bản Mỹ thuật.

9. Tổng Cục Địa chất và Khoáng sản Việt Nam, Liên hiệp các hội khoa học và kỹ thuật Việt Nam, Viện Tu vấn Phát triển, 2010. Báo cáo nghiên cứu đánh giá Thực trạng về quản lý khai thác và sử dụng tài nguyên khoáng sản Việt Nam.

10. Sở TNMT tỉnh Tuyên Quang, Báo cáo định kỳ kết quả HĐKS trên địa bàn tỉnh Tuyên Quang các năm 2011 đến 2018.

11. UBND tỉnh Tuyên Quang, Báo cáo tình hình HĐKS các năm từ 2010 đến 2018.

12. UBND tỉnh Tuyên Quang, 2017. Quyết định số 514/QĐ- UBND ngày 31/12/2017 phê duyệt Báo cáo điều chỉnh, bổ sung "Quy hoạch thăm dò, khai thác và sử dụng khoáng sản tỉnh Tuyên Quang đến năm 2020, tầm nhìn đến năm 2030”. 
13. UBND tỉnh Tuyên Quang, 2018, Quyết định về việc ban hành phương án bảo vệ khoáng sản chưa khai thác trên địa bàn tỉnh Tuyên Quang, số 77/QĐ-UBND ngày $23 / 3 / 2018$.

14. Huỳnh Quang Vinh, 2014. Quản lý tài nguyên khoáng sản ở cấp địa phương: Thách thức và bất cập chính sách. Hội thảo khoa học: Phân cấp và các sáng kiến quản trị tốt tài nguyên khoáng sản ở cấp địa phương. Sở Công Thương tỉnh Bình Định phối hợp cùng Trung tâm Con người và Thiên nhiên.

\section{Assessing the state management of mineral exploitation in Tuyen Quang province period 2011-2018 and proposing the solution till 2030}

\section{Trinh Phuong Ngoc, Kieu Thi Hai, Tran Thi Nhung}

\section{Article info}

Recieved:

25/8/2019

Accepted:

$10 / 12 / 2019$

Keywords:

State management; mineral exploitation; assess; solution; Tuyen Quang

\begin{abstract}
Mineral exploitation is an ongoing activity in Tuyen Quang province. With the characteristics of the mining industry, it has caused many negative impacts on the environment but brought about high economic value. This makes the state management of mineral exploitation really difficult in finding the way to balance between environmental protection and economic development. Minerals in Tuyen ; Quang is distributed in almost all districts and cities in the province and mainly small scattered mines are only suitable for local industrial development. Good implementation of state management on mineral exploitation not only helps to protect the environment but also increases the budget revenue, effectively serving the local socio-economic development. The study focused on evaluating the state management of mineral exploitation in Tuyen Quang province in the period from 2011 to 2018 and the proposed solutions to 2030 .
\end{abstract}

